Журнал «Герспективитаінноваціїнауки»

(Серія «Педагогіка», Серія «Гиихологія», Серія«Медицина»

№5(5) 2021

УДК 37.018.5:005.32

https://doi.org/10.52058/2786-4952 -2021-5(5)-172-184

Гой Наталія Василівна кандидат економічних наук, доцент кафедри управління та бізнес-адміністрування, Прикарпатський національний університет імені Василя Стефаника, вул. Шевченка, 57, м. Івано-Франківськ, 76018, тел.: (034) 259-61-57, e-mail: nataliya.hoy@ pnu.edu.ua, http://orcid.org/0000-0001-7293-6527

Нестеренко Світлана Василівна кандидат педагогічних наук, спеціаліст вищої категорії, викладач-методист, заступник директора з навчально-виховної роботи, Відокремлений структурний підрозділ «Івано-Франківський фаховий коледж Прикарпатського національного університету імені Василя Стефаника», вул. Бандери, 1, м. Івано-Франківськ, 76000, тел.: (0342) 57-00-08, e-mail: svitlana.nesterenko@pnu.edu.ua, https://orcid.org/0000-0001-9943-4383

Драган Оксана Борисівна спеціаліст вищої категорії, викладач, Відокремлений структурний підрозділ «Івано-Франківський фаховий коледж Прикарпатського національного університету імені Василя Стефаника», вул. Бандери, 1, м. Івано-Франківськ, 76000, тел.: (0342) 57-00-08, e-mail: oksanadragan85@gmail.com, https://orcid.org/0000-0003-3660-6576

\title{
СТРАТЕГІЧНЕ ПЛАНУВАННЯ ЯК ОСНОВА РОЗВИТКУ ЗАКЛАДУ ФАХОВОЇ ПЕРЕДВИЩОЇ ОСВІТИ
}

Анотація. У статті обгрунтовано актуальність проблеми впровадження принципів стратегічного управління до організаційної моделі закладів фахової передвищої освіти. На основі теоретичного аналізу визначено особливості розвитку освітніх закладів у сучасних умовах ринку на основі реалізації принципів стратегічного управління, в процесі якого формулюється місія функціонування закладу, проектується та реалізується стратегічна програма на довгострокову перспективу. У науковому дослідженні визначено, що стратегічне планування $\epsilon$ відносно самостійною складовою процесу управління. Теорія і практика управління в системі освіти України завжди надавала великого значення науковому обгрунтуванню, розробці цілепокладання й планування роботи закладів фахової передвищої освіти, що знайшло відбиток в науково-методичних публікаціях різних років. Доведено, що вивчення проблем управлінської діяльності керівників закладів освіти підтверджує потребу науково-методичної допомоги у процесі складання планів різного рівня для керівників у освітній сфері. Дієвість стратегічного планування в закладі освіти, зв'язок теорії і практики аналізу забезпечується прикладним характером та дотриманням науково обгрунтованих принципів. 
Сучасне стратегічне планування базується на усвідомленні учасниками навчально-виховного процесу освітнього закладу потреби в конкретних результатах діяльності 3 огляду на досягнення цілей та завдань у довгостроковій перспективі. У соціально-економічних умовах впливу факторів зовнішнього та внутрішнього середовища, які визначаються глобалізацією ринку освітніх послуг, необхідністю стимулювання переходу економіки на модель інноваційного розвитку, а також дефіцитністю бюджетного фінансування наявної мережі закладів фахової передвищої освіти. Авторами доведено, що виникає необхідність проведення поглиблених досліджень, спрямованих на вироблення теоретичних, методологічних та науковопрактичних основ стратегічного планування для закладів передвищої фахової освіти в умовах дії ринкових ризиків.

Ключові слова: стратегічне управління, стратегічне планування, система управління, заклад фахової передвищої освіти, наукові принципи, стратегія.

Hoi Nataliya Vasylivna $\mathrm{PhD}$ in Economics, Associate Professor of Management and Business Administration, Vasyl Stefanyk Precarpathian National University, Shevchenko St., 57, Ivano-Frankivsk, 76000, tel.: (034) 259-61-57, e-mail: nataliya.hoy@pnu.edu.ua, http://orcid.org/0000-0001-7293-6527

Nesterenko Svitlana Vasylivna Candidate of Pedagogical Sciences, Specialist of the highest category, teacher-methodologist, Deputy Director for Educational Work, Ivano-Frankivsk Professional College of Vasyl Stefanyk Precarpathian National University, S. Bandery St., 1, Ivano-Frankivsk, 76000, tel.: (0342) 570008, e-mail: svitlana.nesterenko@pnu.edu.ua, https://orcid.org/0000-0001-9943-4383

Dragan Oksana Borysivna Specialist of the highest category, teacher, IvanoFrankivsk Professional College of Vasyl Stefanyk Precarpathian National University, S. Bandery St., 1, Ivano-Frankivsk, 76000, tel.: (0342) 57-00-08, e-mail: oksanadragan85@gmail.com, https://orcid.org/0000-0003-3660-6576

\section{STRATEGIC PLANNING AS A BASIS FOR THE DEVELOPMENT OF THE INSTITUTION OF PROFESSIONAL PRELIMINARY EDUCATION}

Abstract. The urgency of the problem of introduction of strategic management principles to the organizational model of professional higher education institutions is substantiated in the article. Based on theoretical analysis, the peculiarities of the development of educational institutions in modern market conditions based on the implementation of the principles of strategic management, in which the mission of the institution is formulated, designed and implemented long-term strategic program. In the study was found that strategic planning is a relatively independent component of the management process.

The theory and practice of management in the Ukrainian education system has 
always attached great importance to scientific substantiation, development of goalsetting and planning of professional higher education institutions, which is reflected in scientific and methodological publications of different years. It is proved that the study of managerial activity problems of educational institutions heads confirms the need for scientific and methodological assistance in the process of drawing up plans of different levels for leaders in the field of education.

The effectiveness of strategic planning in the educational institution, the connection of theory and practice of analysis is ensured by the applied nature and adherence to scientifically sound principles. Modern strategic planning is based on the awareness of the educational process institutions of the educational institution of the need for concrete results of activities in view of the achievement of goals and objectives in the long run. In the socio-economic conditions of the influence of external and internal factors, which are determined by the globalization of the market of educational services, the need to stimulate the transition of the economy to the model of innovative development, as well as the lack of budget funding.

The authors prove that there is a need for in-depth research aimed at developing theoretical, methodological and scientific-practical bases of strategic planning for institutions of higher professional education in the face of market risks.

Keywords: strategic management, strategic planning, management system, institution of professional higher education, scientific principles, strategy.

Постановка проблеми. Сучасний розвиток українського суспільства, прагнення України досягти стандартів європейської спільноти заохочують вивчати світовий досвід формування системи стратегічного управління закладів фахової передвищої освіти, аналізувати структурні складові позитивного іміджу управлінських інституцій в освітній сфері, розробляти власні ефективні моделі відповідно до умов функціонування та національних традицій. Основою розвитку закладів фахової передвищої освіти в Україні згідно вимог ринкової конкуренції та основних аспектів реформування освітнього простору має стати активна реалізація ключових принципів стратегічного менеджменту, в процесі якого визначається місія функціонування закладу, проектується та реалізується стратегічна програма чи стратегія розвитку, вирішуються стратегічні завдання управління. Впровадження основних принципів стратегічного менеджменту до організаційної моделі управління закладами фахової передвищої освіти $\epsilon$ об’ єктивною вимогою сучасності.

Заклади фахової передвищої освіти є суб‘єктами ринку освітніх послуг, на яких розповсюджується дія об'єктивних ринкових законів. Таким чином, вони вимушені вступати у конкурентну боротьбу за доступ до економічних ресурсів, вчасно протидіяти негативним чинникам зовнішнього та внутрішнього середовища, вживати заходів щодо зміцнення власного ресурсного потенціалу, удосконалювати механізми проєктування управлінських рішень, зокрема удосконалювати систему стратегічного 
планування. Як у інших сферах економічної діяльності, у освітній сфері існує конкуренція, а також різні атрибути конкурентної боротьби - демпінг, реклама, недружні атаки, негативний PR тощо. Це означає, що у освітній галузі проявляються різнопланові ринкові та поза ринкові ризики діяльності, які можуть бути ідентифіковані та мінімізовані в процесі застосування менеджментом закладів фахової передвищої освіти методології стратегічного планування.

У сучасних соціально-економічних умовах, які визначаються глобалізацією ринку освітніх послуг, необхідністю стимулювання переходу економіки держави на модель інноваційного розвитку, а також дефіцитністю бюджетного фінансування наявної мережі закладів освіти, виникає необхідність проведення поглиблених досліджень, спрямованих на формування теоретичних, методологічних та науково-практичних основ стратегічного менеджменту в закладах освіти під впливом ринкових ризиків. Необхідно проаналізувати процеси проєктування стратегічних рішень, а також обгрунтовані методичні підходи до формування та реалізації моделей стратегічного менеджменту, враховуючи особливості діяльності закладу фахової передвищої освіти в умовах ринкової конкуренції.

Розвиток стратегічного планування необхідно розглядати як обов'язковий інструмент удосконалення системи управління закладів фахової передвищої освіти, що має значний вплив як на підвищення дієвості інструментів стратегічного управління, так і на вдосконалення складових ефективної діяльності освітніх закладів загалом.

Аналіз останніх досліджень і публікацій. Теорія і практика управління в системі освіти України завжди надавала великого значення науковому обгрунтуванню, розробці цілепокладання і планування роботи закладів освіти, що знайшло відбиток в науково-методичних публікаціях різних років. Проте вивчення проблем управлінської діяльності керівників закладів в освітній сфері підтверджує, що значна частина управлінців потребує науково-методичної допомоги у процесі складання планів різного рівня. Стратегічне планування базується на усвідомленні учасниками навчально-виховного процесу освітнього закладу потреби в конкретних результатах. При цьому мета виступає як спроєктований результат i активізуючий чинник професійної діяльності. У цьому контексті майже всі вчені першою та чи не найважливішою функцією управлінської діяльності вважають стратегічне планування, яке вимагає передбачення основних тенденцій розвитку освітнього закладу. Сучасні наукові школи також приділяють значну увагу реалізації функції стратегічного планування.

На сьогодні не існує єдиного розуміння сутності стратегічного планування в закладах фахової передвищої освіти та його термінології. Найбільше плутанини й непорозумінь виникає при тлумаченні таких термінів, як стратегічний план і стратегія, стратегічне i довгострокове планування, планування й управління. Питання трактування сутності та однакового 
розуміння термінології має фундаментальне значення для будь-якого наукового дослідження, тому потреба в його вирішенні надзвичайно важлива для подальшого дослідження інструментів стратегічного планування в закладах фахової передвищої освіти.

Сучасні теоретичні розробки у сфері стратегічного планування беруть свої витоки 3 теорії стратегічного планування у сфері корпоративного менеджменту, засновником якої вважається I. Ансофф. Ця теорія була розвинута і доповнена рядом інших науковців, зокрема, А. Акер, Р. Акофф, П. Друкер, Б. Карлоф, Дж. Б. Куїнн, Г. Мінцберг, Дж. Стейнер. Серед вітчизняних учених великий внесок у розвиток стратегічного планування зробили О. Машков, В. Горбулін, Н. Нижник, В. Віханський, О. Трухан та ін. У працях цих науковців наводиться чимало різних визначень стратегічного планування, які розкривають ті чи інші його важливі аспекти та особливості.

Проте, незважаючи на теоретичні здобутки у сфері зазначеної проблеми, ми вважаємо, що дослідження сутнісних характеристик має носити системний характер, що у свою чергу сприятиме підвищення якості стратегічного планування та ефективності досягнення прийнятих рішень в управлінні закладами фахової передвищої освіти.

Мета статті - дослідження особливостей формування системи стратегічного планування в умовах реформування освітньої сфери як важливої складової стратегічного управління в закладах фахової передвищої освіти.

Виклад основного матеріалу. Основне призначення організації стратегічного планування в закладах освіти - це визначення оптимальних орієнтирів педагогічної діяльності, мобілізація творчих здібностей педагогічного колективу на безперервне вдосконалення процесів навчання та виховання, програмування роботи, забезпечення взаємного проникнення розумового, морального, трудового, фізичного й естетичного виховання.

Розробка основ оптимального управління у сфері освіти неможлива без глибокого аналізу позитивних тенденцій, узагальненого досвіду суспільного розвитку у вигляді наукових надбань та їх трансформації в управління об’єктами освіти відповідно до їх специфіки і умов діяльності. В останні роки досить активно досліджувалися проблеми управління закладами освіти у зв'язку із прийняттям важливих законопроєктів в галузі управління освітніми закладами.

Багато науковців не відокремлюють планування від менеджменту, стверджуючи, що, як планування, так і менеджмент- це по суті, одне й те саме для прийняття рішень щодо майбутньої діяльності навчального закладу. Р. Акофф вважає, що планування - це розроблення бажаного майбутнього, а також способів, якими його можна було б реалізувати [1, с. 12], а Н. Снайдер визначав планування як діяльність, що стосується завчасного визначення того, які дії або людські й фізичні ресурси потрібні для досягнення цілі. Г. Мінцберг зазначає, що аналогічно цьому в певних джерелах державного сектору термін 
«планування» використовувався як синонім «прийняття рішень» і «проектний менеджмент» [3, с. 9].

На думку I. Ансоффа, вибір стратегії та формування політики насамперед $\epsilon$ процесом прийняття рішення: по-перше, це встановлення цілей, після чого із застосуванням серії аналітичних методів визначаються альтернативи та здійснюється вибір між ними [4, с. 8]. У свою чергу, Г. Мінцберг критикує таке визначення, вказуючи на те, що описаний спосіб вироблення стратегії далеко не єдиний. Проте планування та інтуїтивні рішення менеджерів $є$ речами протилежними. Отже, сам факт прийняття рішення ще не означає, що було застосовано планування [3, с. 11]. Г. Мінцберг вважає, що планування відрізняється від інших видів прийняття рішень формалізацією процесу. «Планування - це формалізована процедура, спрямована на отримання чітко визначеного результату, яка має форму інтегрованої системи рішень. Те, чим найбільше приваблює поняття планування, що $\epsilon$ характерною рисою та відрізняє його методи від інших процесів, - це наголос на формалізації та систематизації явища, до якого застосовується планування»; у цьому контексті формалізація, за Г. Мінцбергом, означає: розкладання на компоненти; їх чітке формулювання; формалізацію процесів прийняття рішень та їх інтегрування в організаціях [3, с. 11].

Отже, планування, як і менеджмент, за своєю суттю є процесом прийняття рішень щодо майбутньої діяльності організації, але відмінність між ними полягає в тому, що планування - це формалізований i системний процес прийняття управлінських рішень, що є його відмінною і ключовою ознакою. У наведених цитатах I. Ансоффа та Г. Мінцберга поняття «стратегія» вживається як синонім до поняття «план». «Стратегія - генеральний план дій, який визначає пріоритети стратегічних завдань, ресурси і послідовність кроків щодо досягнення стратегічних цілей» [5, с. 133]. «Стратегія - це план, що інтегрує в деяке узгоджене ціле такі компоненти: головні цілі організації; політику (цінності, філософію, ідеологію); застосовувані дії» [6, с. 20]. «Стратегія - це комплексний план діяльності підприємства, який розробляється на основі творчого науково обгрунтованого підходу i призначається для досягнення довгострокових глобальних цілей» [7, с. 9]. Проте трапляються й інші визначення стратегії як моделі взаємодії організації із зовнішнім середовищем або набору чи системи певних принципів та правил.

На нашу думку, стратегічний план - це план реалізації стратегії як певної моделі поведінки організації, яка має забезпечити їй конкурентні переваги. Цінність стратегії полягає в тому, що вона $\epsilon$ моделлю поведінки, набір принципів i правил, дотримуючись яких організація здатна забезпечити конкурентні переваги та виживання на ринку. Якісна чи правильно вибрана стратегія не потребує змін залежно від змін зовнішнього середовища, оскільки вона сама по собі $є$ необхідною умовою виживання в умовах постійних змін, тоді як стратегічний план як комплекс інтегрованих і взаємопов'язаних у просторі і часі дій повинен постійно коригуватися залежно від зовнішніх 
обставин та вибраної стратегії.

Отже, стратегія - це модель поведінки, спрямованої на досягнення поставлених цілей, набір правил для пошуку і використання можливостей. Стратегічний план - послідовність певних кроків та дій, інтегрованих у просторі і часі, що приводять до зміни поточного становища на бажане. План не має гнучкості і реалізується тільки за певних зовнішніх умов, стратегія застосовувана в будь-яких ситуаціях. План повинен постійно коригуватися залежно від змін у зовнішньому середовищі, тоді як стратегію потрібно змінювати тільки при внутрішніх змінах (за власним бажанням). Існують довготривалі плани роботи організації, метою яких не $\epsilon$ досягнення стратегічних орієнтирів. Стратегічний план в закладі освіти - це план реалізації стратегії як певної моделі поведінки, яка має забезпечити розвиток організації в конкурентних умовах. Таким чином, відмінність стратегічного плану від інших насамперед полягає в тому, що в його основу покладена стратегія.

Однією з перших спроб запропонувати модель розвитку закладів освіти в умовах оновлення суспільства, була колективна наукова діяльність Ю. А. Конаржевського, К. О. Нефедової, Т. І. Шамової. У 90-ті роки минулого століття в умовах демократизації суспільства й управління в сфері освіти планування роботи перестало жорстко регламентуватися. 3'явились методичні рекомендації з цієї проблеми. Певний інтерес викликає структура планування в ідеалі: мета; змістовна частина, модель об'єкта діяльності (структура, принципи внутрішньої організації та особливості функціонування об'єкта, теоретичне обгрунтування проблеми); параметри стану об'єкта діяльності; технологія (основні шляхи досягнення мети цільового проекту та їх обгрунтовування); кадрове забезпечення цільового проекту; організаційне забезпечення цільового проекту; матеріально-технічна база; фінансове забезпечення.

Методичною основою планування роботи у закладах освіти на сьогодні $\epsilon$ принципові положення управління закладами освіти. В основу стратегічного планування освітнього процесу покладені такі основні принципи: цілепокладання, науковості, системного підходу, доцільності, наступності, колегіальності, інноваційності.

Дотримання зазначених принципів передбачає істотну зміну завдань управлінської діяльності керівника, мети, змісту, форм та методів його роботи. Зокрема, метою управління освітнім закладом, який здійснює інноваційну діяльність, вважається постійне оновлення освітнього процесу, що дає позитивні результати; змістом управління - виконання керівником модернізованих управлінських функцій: прогнозування, політикодипломатичної, консультативної, менеджерської, представницької; запровадження нових форм і методів управління, колективних і колегіальних форм управління; техніко-технологічних та економічних методів.

У процесі складання стратегічних планів діяльності закладу фахової передвищої освіти, виходячи 3 принципових положень планування, слід 
дотримуватися таких вимог: враховувати конкретні умови й специфіку освітнього закладу; забезпечити варіативність форм; відійти від догматичних повторень й штампів при формуванні змісту; не боятися змінювання форми і структури планів; категорично відмовитися декларативності; включати в плани роботи тільки те, що можна реально виконати; не допускати зайвої деталізації та завантаження планів другорядними питаннями. Плани повинні бути максимально лаконічними, чіткими і наочними щодо відображення інформації, бажано модельного характеру 3 визначеною структурою, яка легко сприймається.

На нашу думку, усвідомлення вищезазначених теоретичних аспектів планування розвитку освітнього закладу $\epsilon$ обов'язковими умовами успіху діяльності: знання того рівня, на якому перебуває система до початку планування; чітке уявлення про бажаний рівень, до якого треба дійти наприкінці запланованого періоду; вибір ефективних шляхів і засобів планової діяльності.

Процесу стратегічного управління повинна приділятися систематична увага $з$ боку керівників освітніх закладів 3 безумовними дотриманням всіх викладених принципових положень і вимог. Щодо кількості видів, структури, форм планування, то виходячи 3 основної ідеї: планування $\epsilon$ різновидом прогностичного моделювання, яке повинно відображати зміст, місце і терміни вирішення конкретних завдань, які ведуть до реалізації головної мети. Виходячи $з$ цього за умови різноманітності освітніх закладів в Україні не можна вважати науковим й практично доцільним регламентування кількості, видів, структури і форм планування роботи навчальних закладів. Враховуючи їх різноманіття і специфіку, ці моделі мають науково обгрунтоване (а не формально-адміністративне) право на творчу самостійність за кількістю, змістом, структурою та формами, які визначаються адміністрацією конкретного навчального закладу (головне - щоб при їх складанні були витримані принципові положення та вимоги щодо планування).

Забезпечення конкурентоспроможності, робота над підвищенням якості всіх видів освітніх послуг, розвиток довгострокових партнерських зав'язків 3 закладами освіти різного рівня дозволяє реалізувати науковий та освітній потенціал, виявити найбільш ефективні шляхи подолання труднощів, що стоять сьогодні перед освітнім комплексом, по-новому поглянути на вже сформовані управлінські рішення. Збалансований підхід до аналізу завдань підвищення ефективності управління дає можливість об'єднати в одне ціле практичні розробки, що виникли на основі багаторічного досвіду розвитку програм професійної освіти. Таким чином, одним з основних умов оптимізації системи стратегічного планування освітніх закладів є цільова орієнтація на досягнення максимальної економічної ефективності. Збалансований підхід до аналізу завдань підвищення ефективності управління навчальним процесом у закладах освіти дає можливість об'єднати в одне ціле практичні розробки, що виникли на основі багаторічного досвіду розвитку програм освітньої сфери. 
Таким чином, однією 3 основних умов оптимізації системи стратегічного планування закладів освіти є цільова орієнтація на досягнення максимальної економічної ефективності. Освітня система, що склалася в останні роки, орієнтується на розвиток ринкових відносин, має можливості самоорганізації. У структурі грошових витрат громадян зростає частка, пов'язана з отриманням освітніх послуг протягом усього життя. Конкуренція в сфері освіти переходить на якісно новий рівень й приймає нові форми [2].

Розвиток ринку освітніх послуг відбувається за рахунок сприятливої економічної кон'юнктури, стійкого зростання реальних грошових доходів, широкого спектра освітніх послуг, диференціації вартості навчання, що забезпечують платоспроможний попит населення. $\mathrm{У}$ той же час незбалансованість ринкових перетворень на різних рівнях освітньої системи, недостатність наступності різних освітніх рівнів, незавершеність інституціональних трансформацій, активна конкуренція закладів освіти країнсусідів, світова фінансова криза загострює економічні проблеми отримання якісної освіти. Для освітніх систем стали характерними наступні тенденції розвитку:

- забезпечення доступності освіти для різних верств - освіта стає інклюзивною;

- зростає масовість освіти (перехід до загальної вищої освіти в економічно розвинених країнах);

- комерціалізація вищої освіти;

- конкуренція перемістилася з локального на глобальний рівень;

- престижність закордонного диплома в країнах, що розвиваються, i країнах з перехідною економікою;

- «концентрація умів» в провідних університетах;

- стрімке оновлення інформаційно-комунікаційних технологій і розвиток нових можливостей і форм навчання на їх основі;

- втрата актуальності знань (необхідність оновлення знань кожні 5-7 років);

- знання стали товаром;

- період віддачі інвестицій в освіту подовжується;

- глобалізація освіти, через розширення можливостей міжнародного співробітництва призводить до інтеграції освіти;

- освіта протягом усього життя і самоосвіта - стають основою особистої конкурентоспроможності;

- перехід від концепції функціональної підготовки до концепції розвитку особистості.

Глобалізаційні процеси закономірно виявляються в сфері освіти як інтернаціоналізація викладацького складу та студентського контингенту. Розвиток академічних свобод для українських закладів фахової передвищої освіти відбувається, перш за все, як процес переходу від державного контролю до державного регулювання [6]. Зростає рівень академічної свободи. Однак зі 
зростанням свободи відповідальність закладів фахової передвищої освіти переміщається від забезпечення відповідності умов мінімальним вимогам на забезпечення відповідності результатів вимогам реальних секторів економіки i суспільства.

Вимоги споживачів як вступників, так і тих, хто вже навчається також змінюються. Самі споживачі стали більш обізнаними в специфіці навчання, стали стежити за позицією закладу освіти в різних рейтингах. Крім цього змінилася структура попиту абітурієнтів. Збільшилася потреба в навчанні українською та англійською мовами, з'явився попит на нові спеціальності, тісно пов'язані із застосуванням інформаційних технологій. З'явилися нові категорії споживачів. Зміну вимог споживачів i зацікавлених сторін характеризують:

- підвищення рівня вимог споживачів до якості освітніх послуг;

- різноманітність потреб населення,

- розширення попиту на види і рівні освітніх послуг;

- нестабільний попит;

- потреба в зниженні оплати за навчання внаслідок низького рівня доходів потенційних споживачів;

- активізація роботодавців;

- збільшення ступеня академічної свободи.

Освітньому середовищу в Україні властиві:

- скорочення термінів впровадження освітніх продуктів;

- розвиток супутніх і обслуговуючих освіту сфер діяльності;

- збільшення асортименту освітніх послуг - нові освітні програми в рамках спеціальності;

- старіння педагогічних кадрів;

- нестача молодих викладачів;

- розвиток інформаційно-комунікаційних технологій;

- залучення зарубіжних викладачів;

- розвиток академічної мобільності викладачів і студентів;

- гармонізація змісту освітніх програм;

- орієнтація освітніх програм на професійні стандарти i рамки кваліфікацій.

Стратегічне планування передбачає дві методології планування в залежності від типу системи «жорсткої» або «м'якої» [7]. Характерною особливістю освіти є розуміння як «м'якої», нечіткої системи. Методологія «м'яких» систем заснована на двох альтернативних парадигмах, які пояснюють природу і значення системного мислення $[2,7]$ : одна розглядає дійсність як системну діяльність, а інша розглядає світ як проблематичний, можливо системний, але допускає багато інтерпретацій (причому така реальність вивчається теж узгоджено). Методологія м'яких систем, розглядається як технологія стратегічного планування в умовах неструктурованих проблемних ситуацій. 
Журнал«ГЕрспективита іновації науки»

(Серія«Гедагогіка», Серія«ПЕихологія», Серія «Медицина»

№5(5) 2021

Стратегічне планування оцінює перспективи, виявляє можливості й загрози зовнішнього середовища, сильні й слабкі сторони внутрішнього середовища, також аналізує зміни конкурентної позиції закладу фахової передвищої освіти на ринку освітніх послуг. Стратегічне планування визначають як формалізований процес постановки стратегічних цілей й розробки багатоваріантного стратегічного плану їх досягнення на основі обраної стратегії.

Основними компонентами стратегічного планування в закладах фахової передвищої освіти є:

- системний аналіз внутрішнього і зовнішнього середовища;

- встановлення стратегічних цілей та орієнтирів;

- визначення стратегії їх досягнення;

- розробка стратегічного плану їх досягнення.

Стратегічне планування за своєю суттю спрямоване на управління змінами, з майбутнього в сьогодення і покликане дати відповідь на запитання: «яким чином можна досягнути поставлених цілей». Результатом стратегічного планування є стратегічний план, який визначає головні завдання, кроки та ресурси, необхідні для досягнення стратегічних цілей 3 визначенням виконавців та термінів.

Серед класичних підходів, що застосовуються для розробки стратегії закладу фахової передвищої освіти, можна виділити теорію обмежень, яка дозволяє на основі різних матриць обмежень (матриці BCG, McKinsey, Aнсофа та ін.) зменшити невизначеність, зрозуміти цілісну картину ситуації.

Стратегічне планування в цьому випадку передбачає визначення компромісу у виборі пріоритетів між:

- низькими витратами і диференціацією освітніх послуг,

- зростанням частки ринку й підвищенням прибутковості на вкладений капітал;

- зростанням вартості та залученням великого учнівського контингенту;

- прибутковістю й ліквідністю та ін.

Застосування різних інструментів при розробці стратегії закладу фахової передвищої освіти, проведення аналізу внутрішнього й зовнішнього середовища в різноманітних формах, виявлення чинників, що стримують розвиток освітнього закладу i факторів, що сприяють йому, можливість розробити унікальну стратегію, що дозволяє ефективно досягти успішних результатів та мети стратегічного планування. Просування закладу освіти та досягнення стратегічних цілей сприятиме розвитку та підвищенню його конкурентоспроможності [8].

Стратегія розвитку закладів фахової передвищої освіти відображена у стратегічних планах. Основним стратегічним документом освітнього закладу $є$ стратегічний план розвитку. Метою стратегічних планів $є$ комплексний розвиток освітньої системи, а також кожного учасника освітнього процесу, 
визначення стратегії пріоритетного розвитку освітнього закладу як важливого чинника економічного i соціально-культурного розвитку. Цей план можна розглядати як проєкт системного реформування закладу освіти, при якому інновації зачіпають істотні сторони навчально-виховного процесу. Стратегія розвитку відноситься до масштабного довгострокового планування, що має на меті вирішити поставлені перед закладом завдання протягом тривалого періоду.

Висновки. Ефективне управління закладами фахової передвищої освіти передбачає стратегічну орієнтацію діяльності педагогічного колективу та узгодженість планів структурних підрозділів, відповідальних за реалізацію цілей закладу. Воно здійснюється в контексті окресленої стратегії та його основним завданням є забезпечення взаємозв'язку місії з основними цілями закладу освіти в умовах мінливого соціального середовища. Використання технологій стратегічного управління в закладі фахової передвищої освіти можливе тоді, якщо заклад є стратегічно орієнтованим. Це означає, що керівництво володіє стратегічним мисленням, застосовується система стратегічного планування, а повсякденна діяльність закладу освіти підпорядкована досягненню поставлених стратегічних цілей. Стратегічне управління уможливлює своєчасну реакцію закладу освіти на зміни зовнішнього середовища в освітній, науково-технічній, соціальній й політичній cфepax.

\section{Jimepamypa:}

1. Ackoff R. Concept of Corporate Planning. New York : John Wiley \& Sons, 1970.

2. Snyder N., Glueck W.F. How managers plan - the analysis of managerial activities. Long Range Planning 13(1). 1980. P. 70-76.

3. Мінцберг Г. Зліт та падіння стратегічного планування. К. : Вид-во Олексія Капусти. 2008. 389 c.

4. Ансофф И. Стратегическое управление. М. : Экономика. 2005. 519 с.

5. Ільник В. К. Технологія стратегічного планування діяльності загальноосвітнього навчального закладу // Теорія та методика управління освітою. № 3. 2010. С. 24-56.

6. Про вищу освіту. Закон України від 1 липня 2014 року, № 1556-VII. https://zakon.rada.gov.ua/laws/show/1556-18. (дата звернення 20.11.2021).

7. Торган М. М. Аналіз сучасних підходів до моніторингу управлінської діяльності керівників навчальних закладів // Теорія та практика державного управління. Вип. 4. 2013. c. $230-235$.

8. Про фахову передвищу освіту. Закон України від 6 червня 2019 року, 2745-VIII. https://zakon.rada.gov.ua/laws/show/2745-19\#Text. (дата звернення 20.11.2021).

\section{References:}

1. Ackoff, R. (1970) Concept of Corporate Planning. New York : John Wiley \& Sons. 125 p.

2. Snyder, N. and Glueck, W.F. (1980) How managers plan - the analysis of managerial activities. Long Range Planning 13(1), 70-76.

3. Mintsberh, H. (2008) Zlit ta padinnia stratehichnoho planuvannia [Rise and Fall of Strategic Planning]. Kyiv. O. Kapusta Publ. 389 p. [in Ukrainian]

4. Ansoff, Y. (2005) Stratehycheskoe upravlenye [Strategic Management]. Moscow. Economics. 519 p. [in Russian] 
5. Ilnyk, V. K. (2010) Tekhnolohiia stratehichnoho planuvannia diialnosti zahalnoosvitnoho navchalnoho zakladu [Technology of Strategic Planning of the Activities of a General Educational Institution]. Teoriia ta metodyka upravlinnia osvitoiu - Theory and Methods of Education Management, 3, 24-56. [in Ukrainian]

6. Zakon Ukrainy "Pro vyshchu osvitu" : vid 1 lypnia 2014 roku, № 1556-VII [Law of Ukraine “On higher education” from July 1, 2014, № 1556-VII]. (n.d.). zakon.rada.gov.ua. Retrieved from https://zakon.rada.gov.ua/laws/show/1556-18 [in Ukrainian].

7. Torhan, M.M. (2013) Analiz suchasnykh pidkhodiv do monitorynhu upravlinskoi diialnosti kerivnykiv navchalnykh zakladiv [Analysis of Modern Approaches to Monitoring the Management Activities of Heads of Educational Institutions]. Teoriia ta praktyka derzhavnoho upravlinnia - Theory and Practice of Public Administration, 4, 230-235. [in Ukrainian]

8. Zakon Ukrainy "Pro fakhovu peredvyshchu osvitu" : vid 6 chervnia 2019 roku, № 2745-VIII [Law of Ukraine "On professional pre-higher education" from June 6, 2019, № 2745-VIII]. (n.d.). zakon.rada.gov.ua. Retrieved from https://zakon.rada.gov.ua/laws/show/2745-19\#Text [in Ukrainian]. 